\title{
The problem of ensuring industrial products quality in Russia
}

\author{
S.B.Baurina \\ E.V.Nazarova \\ E. O. Savchenko \\ G. Plekhanov Russian University of Economics \\ Moscow, Russia
}

\section{Keywords}

quality, industry, machine-tool engineering, radio electronics, defense industry, quality management system.

\begin{abstract}
This paper deals with the problems of industrial products quality in Russia, its control and maintenance. Our analysis of the identified issues is industry-specific: we study how products quality is assured in machine-tool and radio electronics equipment manufacture; some specific features of these processes in defence industry are identified and described. We define the areas where quality management systems can be improved and further developed at machine-tool manufacture plants. We also suggest certain concrete recommendations for developing highly competitive companies that produce radio electronic devices. We propose a system of quality maintenance for defense enterprises.
\end{abstract}

Corresponding author: Svetlana Borisovna Baurina

Email address for corresponding author: editor9@academicpapers.org

First submission received: 23rd November 2016

Revised submission received: 23rd April 2017

Accepted: 6th June 2017

\section{Introduction}

Currently the Russian economy is in a difficult situation. This is facilitated by both a protracted economic crisis and political disagreements between states. The European Union and the United States have applied a package of sanctions against Russia, then additional sanctions restrictions were added in stages, which touched on the most competitive industries: machine-tool building, radio electronic industry, military-industrial complex. Whatever it was, the sanctions to a large extent spurred the efforts of the Russian industry to import substitution, although, of course, led to disruption of the implementation of projects, and somewhere to the rejection of plans.

It is important to bear in mind that under the sanctions regime, the share of imports of metalworking equipment from "unfriendly countries", for example, is $63.3 \%$ (60.8\% of the market); the share of tool imports is $33.3 \%(30.4 \% \%$ of the market). This situation leads to negative consequences from the point of view of technological safety.

Problems and complexities of Russia's economy manifest themselves not only in stagnation, occasionally in dropping industry outputs and instances of cross-default, but also in the level of quality of products being manufactured. The technology level of equipment and know-how generated in Russia are, sadly more often than not, considerably lower than those in industrially advanced economies (Vershinina et al., 2016). Investments in industrial modernisation and new technologies will be worthwhile only if products to be manufactured are competitive and in demand from customers.

The goal of this paper is to present to colleagues our view of the problem of ensuring industrial products quality in a range of manufacturing sectors of Russia's national economy.

The presented materials are designed to facilitate professional development of academic personnel and to set the pace for R\&D work of young researchers and engineers. 


\section{The problem of quality maintenance in machine-tool engineering}

The current state of Russian machine-tool engineering and manufacture does not give any grounds to hope for bringing out to the market sufficient amounts of competitive mechanical processing equipment, in many an area that would be import-substitutive. (Baurina, 2016). Due to this quantitative and qualitative setback - in the context of the sky-rocketing development of machine-tool engineering in the leading economies - Russian machine-tool industry has been gradually losing ground being incapable of competing with the growing imports (Fig. 1).

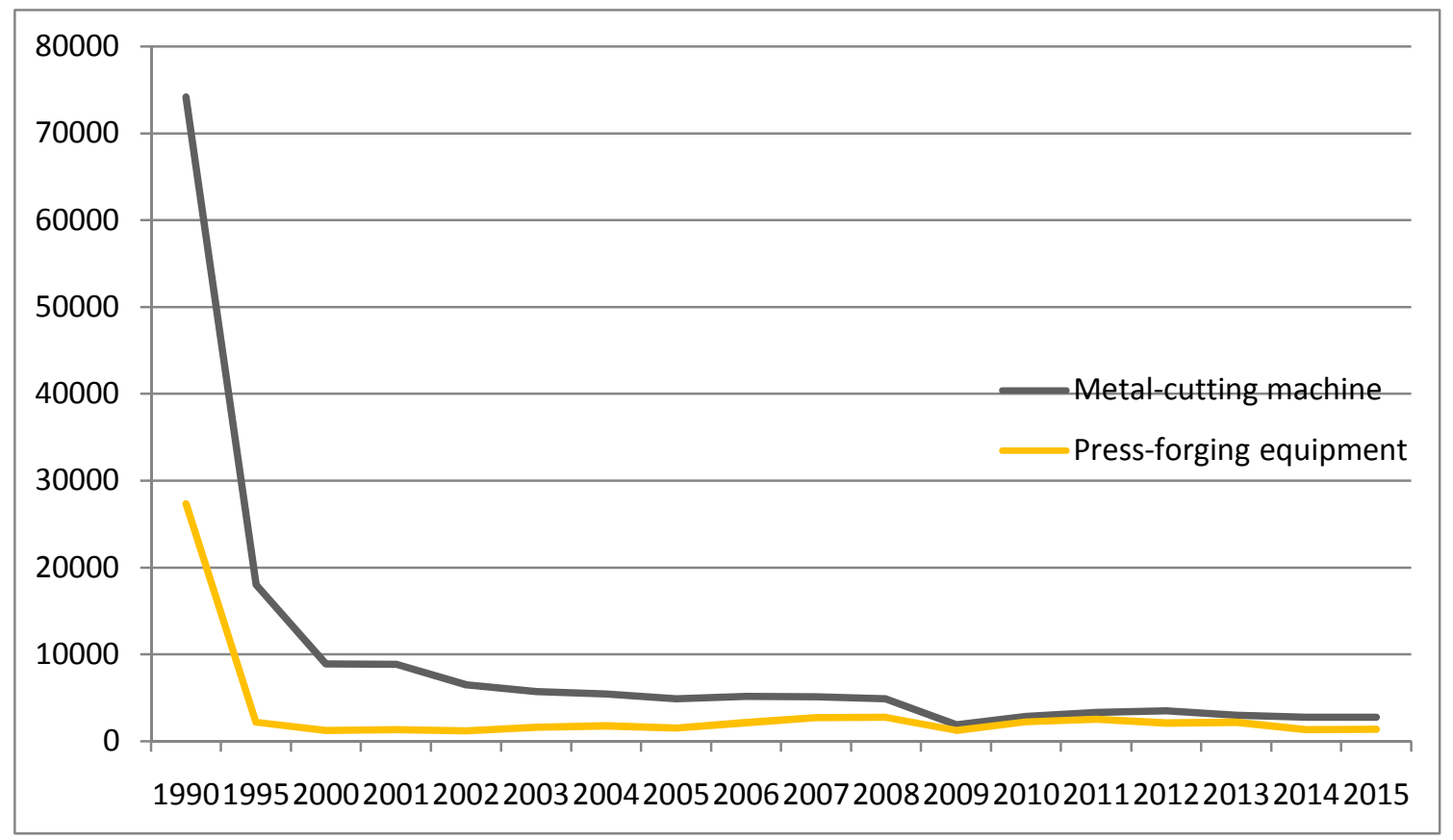

Figure 1. Manufacture of machinery and plants (pcs)

Introduction of new systems of quality management and voluntary certification at machinetool building enterprises in Russia, that could solve issues of quality assurance of the machines and equipment manufacturing, despite the successes that have been made, are slow.

The long practice of using quality management systems at Russian factories and plants of the machine-tool building sector (OJSC "Volgodieselapparat", city of Marks, Saratov region; OJSC "Stankostroitel", city of Saransk; OJSC "Prommash", city of Saratov; OJSC "Elektroterm-93", city of Saratov; LLc EPO "Signal", city of Saratov; OJSC "Stanko Mash Kompleks", city of Tver; PTC "Stanko Stroitel", Moscow, etc), along with the latest research testify to sporadically arising problems, both of the global and local nature.

Let us now look closer at the problems indicated above.

1. The objectives and target performance indicators for developing and implementing quality managements systems seem to be insufficiently clear and well thought-out. First and foremost, it is due to a rather formal approach to the task: a) the object being pursued is chiefly to get a compliance certificate (which allows a company to enter the export market); $b$ ) the very goal of creating an effective quality maintenance system truly conductive to reaching a necessary products quality and competitiveness level is pushed to the sidelines (Nazarova et al., 2016). On balance, what we have is the ill-timed and tardy solutions to a range of important organizational and economic tasks that have long become "overdue".

2. Methodological problems of defining the context/boundaries of the evaluation model. Graded performance evaluation is sometimes lacking: performance evaluation for one 
workplace, for a business unit/subdivision/department, for the company as a whole. Many a specialist tends to think that the outcomes of the processes involved in quality management systems operation are to be defined more clearly. Besides, difficulties do arise in connection with setting performance criteria for quality management systems.

3. Considerable labour input and costs associated with financial accounting for the 'price' of quality maintenance. Such accounting requires introduction of modern forms of bookkeeping (Nazarova et al., 2016). That is why many machine-tool manufacturing enterprises put first the task of making their documentation compliant with the mandatory requirements of the ISO international standard, whereas quality cost accounting becomes less significant.

4. Imperfections of the methods used for quality management systems' performance assessment at machine-tool building plants. There have been observed certain difficulties with estimating real resource expenditure on a quality management system and with calculating the share of profits coming from the quality system's management.

In addition to the above, the practice of machine-tool building factories operation reveals the problem of balanced score card estimation of quality management systems performance (Kubela, Pochyly and Singule, 2016). A robust solution to this is to be approached with regard to such an indicator as satisfaction of all stakeholders, i.e. comprehensively. A correct and reliable evaluation method is what will enable a factory's management to plan their governance activities and set criteria for performance assessment in order to reach all identified goals as per each and any indicator of quality maintenance systems' outcomes.

Quality management systems efficiency upgrade in machine-tool building is to be considered at both macro- and micro-level. The former implies development and implementation of a national quality maintenance policy along with regard to certified QMSs when allocating government contracts for purchase and supply of products to state demands. The latter means introduction of a requirement for additional training and qualifications in the area of quality management, along with meeting appropriate requirements for personnel and implementing staff incentive systems (Wan et al., 2016).

It is quite acceptable, in modern conditions, close cooperation with Asian manufacturers of machine tools and equipment (China, Taiwan, India, Singapore, Malaysia, Korea, etc.). First of all, we are talking about studying and actively using their positive experience in ensuring the quality of products. Despite the EU's sanctions policy, a number of investment projects of foreign investors are successfully implemented: a joint venture of Czech investors with Ekaterinburg's "KR Prom" for the production of horizontal boring machines and portal machining centers; The Pumori group together with the Japanese Okuma manufactures CNC machines, in Perm the machine assembly is carried out in cooperation with the Indian Ace Manufacturing Systems; The project of the German company "Hermle" provides for the creation of a machine-tool plant for the large-unit assembly of milling fiveaxis machining centers on the territory of the industrial park "Zavolzhye".

Improvement of internal activities of Russian manufactories aimed at ensuring high products quality and bettering customer satisfaction will come from efficient practical management solutions, which, in its turn and in the long view, will be conductive to an increase in positive outcomes of deployment and operation of quality management systems at machine-tool building enterprises (Ministry of Industry and Trade of Russia, 2016).

\section{Quality maintenance in radio electronics manufacture}

An urgent issue for the current innovation-centred development of radio electronics manufacture is a solution to the problem of ensuring reliability and high quality of products (State program, 2014). Data on exports/imports turnover in the radio electronics sector is shown on Fig.2. 


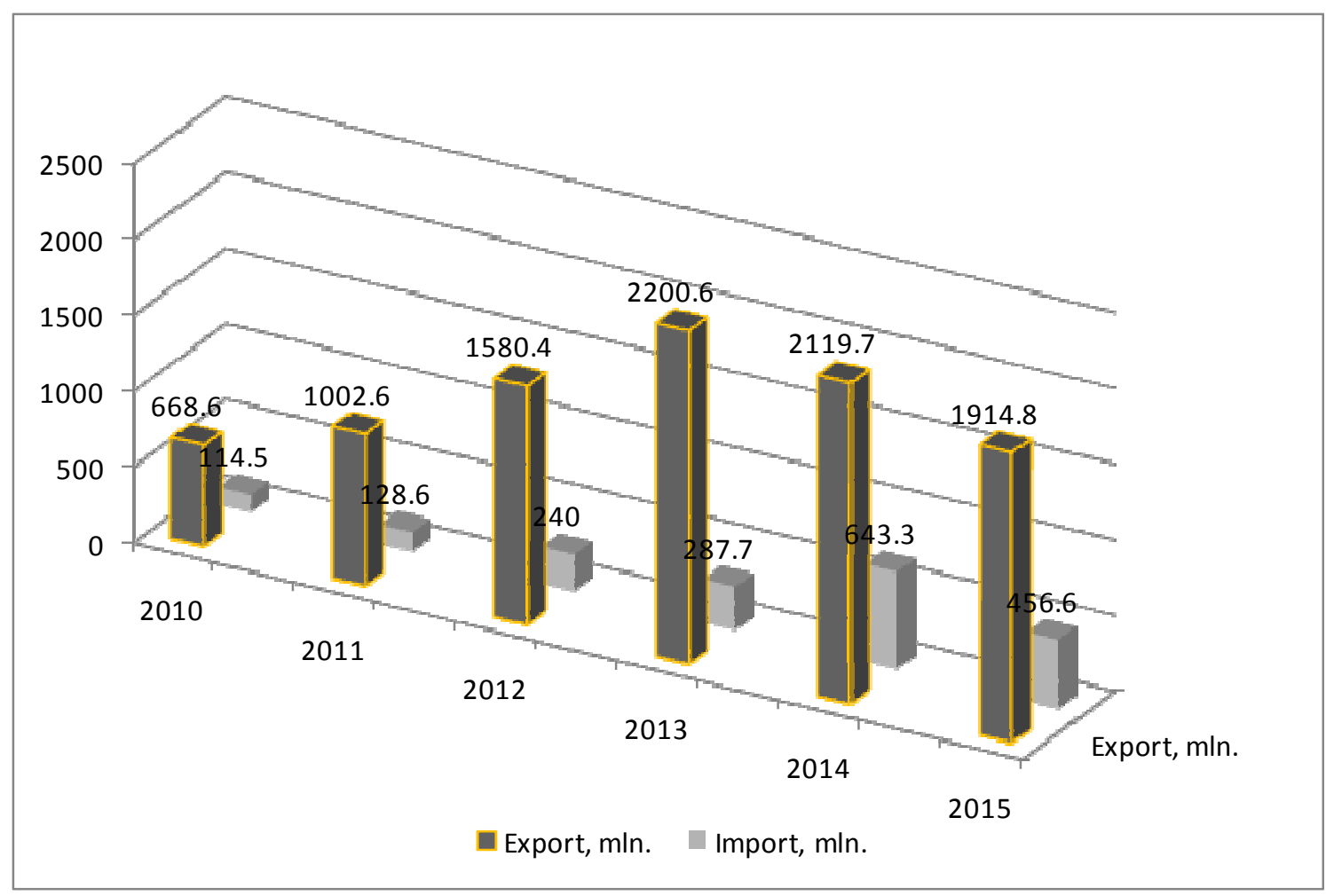

Figure 2 - Data on the volumes of exports and imports of radio electronic products, millions USD (State program, 2012)

Unsatisfactory attention to the issues of communications electronics quality and, due to this, low competitive ability of the products are what has caused a practically total ousting of Russian producers from the consumer market. Sadly, this situation is characteristic of other sectors, too, but in the area of radio electronics manufacture, overcoming product quality difficulties seems to be a much more urgent challenge.

Today, communication equipment manufacturers in Russia badly need substantial investments into fixed assets replacement, scale-up and implementation of new technologies, among other things. A faster modernization of industrial plants, with reliance on a new and novel engineering and technological basis, may be possible if and only if investments are utilized efficiently.

The fundamental goal of state policy now is the improvement of technology level in Russia's communications equipment sector to match the existing global standards, as well as competitive recovery of the products at both domestic and international markets (Vershinina et al., 2015).

The recently obvious increase in the weight of the problem of communications equipment quality has been largely determined by the fact that radio electronic devices and gadgets have become highly sophisticated and at the same time universally used in all and any sphere of industrial production, research and management, leave alone special-purpose applications. The notion of 'quality' in relation to this type of equipment is viewed as an integral indicator determined by the general level of engineering research and development, by the quality of electronic products, by sophistication of know-how and available measurement/testing capabilities.

Let us now identify the key reasons for a drop in product quality demonstrated by Russian manufacturers of radio electronics:

- first, due to curtailed research programs in the field of quality and reliability of radio electronic equipment, the programs that had been active and efficient in 1980 - 1990s; 
- second, due to reduced sharing of best practices between engineers, manufacturers and publishers of specialist and reference literature on the subject;

- third, due to the absent centres of expertise displaying high-accuracy analytical equipment capable of detecting and identifying the causes for and mechanisms of technical failures in communications radio electronics;

- fourth, due to now inexistent supplies of radio electronics from the Baltic states, Ukraine, Kazakhstan, etc. (over 30\% of component), along with production curtailment at a range of Russian factories;

- Fifth, due to existing problems at the level of radio electronic manufacturers: outdated production and testing facilities, insufficiently rapid introduction of technological advances, a lack of appropriately qualified and trained personnel specialists. (Bobalo et al., 2016).

All the identified causes for a reduced quality of Russian communications equipment are due to the general downfall of the country's economy and a sizeable under financing of standardisation, quality maintenance and certification of the products.

Inadequate investment in the radio electronics sector affects, in an adverse manner, the development of hardware component by manufacturers: a range of component parts are not in production any longer. In connection with this, Russian producers are often compelled to purchase components from suppliers that are far from being reliable and trustworthy. At the same time, a proper acceptance control at full scale is in place only for a limited number of special application products. As a consequence, the key reason for equipment malfunctions is component failure.

It appears to be quite obvious that the problem of radio electronics quality must be solved at the very early stages of its lifecycle: i.e. during engineering research and development (Bobalo et al., 2016). However, it ought to be noted that even if a set of desired technological properties is in place, this does not necessarily speak of a 'quality' of equipment. Essential is also the quantitative assessment of the properties making up this 'quality'. The quality of modern radio electronic products is eventually determined by proper organization and management, by methodology and technology of quality control, measurements and testing throughout designing and production stages; none the less important role is also played by the level of metrology employed at the factory.

For a faster and more convincing growth of companies producing radio electronic equipment (subject to product type), a set of requirements are to be met:

- manufacturers in professional segments: flexibility in product development with regard to customer needs, in close integration with the latter; focus on key processes; powerful sales and distribution with a perspective for international operations; full-blown industrial cooperation;

- manufacturers in special segments: good balance between production and cooperation, operational effectiveness, a flexible supply chain structure; focus on key competencies and a high concentration of resources in these areas (Guerra, Sousa and Nunes ,2016).

Isolated and uncoordinated measures aimed at achieving individual targeted indicator values do not guarantee a solution to the problems of maintaining high quality of radio electronic products in general (Afefy, El-kamash and El-Sayar, 2015).

The quality of raw/engineering/finishing materials, of component parts, production tooling and equipment, infusion of high-end technology and implementation of science-based manufacturing process engineering and management, a better structuring of process operations, transition to a higher level of process automation, etc., etc., -- all this collectively is what determines the quality of radio electronics. Another important factor of communications equipment quality is its proper operation, the level of standardisation and unification, economic factors, etc.

\section{Quality assurance in weapons industry}

Defence industry in Russia is very R\&D-intensive. Its frontline research and development is conductive to a technology spill over to other areas of national economy. But, despite the apparent 
successes, the problem of quality maintenance for military materials and equipment (MME) is more than acute.

The abundance of sanctions against a number of defense enterprises in Russia, broken connections between many manufacturers of military hardware components have put manufacturers in a quandary. However, there are examples of successful activities in the current conditions.

So, the American Defense News says about the holding "Almaz-Antey", which specializes in the production of anti-aircraft systems. At the moment, it ranks 11th among the world's largest arms producers, and over the past year has managed to increase its turnover by more than $10 \%$. The Russian Helicopters holding (turnover increased by 16.3\%) and the Tactical Missile Armament Corporation (plus $48.6 \%$ of turnover) achieved even more notable successes (http://www.defensenews.com/).

The key causes for insufficiently high quality of defence products can be categorized as technical, legal and organisational (Table 1).

Table 1. Key reasons for defence products' law quality

\begin{tabular}{|c|c|}
\hline Types & Properties \\
\hline Technical reasons & $\begin{array}{l}\text { - obsolescence and physical wear of the fixed assets (FA) of defence } \\
\text { contractors (DC), including outdated process engineering capabilities and a lack } \\
\text { of modern machine-tools and measuring equipment and lab/test facilities; } \\
\quad-\text { use of outdated hardware component for MME manufacture; a low } \\
\text { quality of components and materials; } \\
\quad \text { - inexistent state-of-the-art electronic tracking equipment in the } \\
\text { development, production and operation of science-intensive MME at all stages of } \\
\text { its lifecycle (CALS-technologies) which ensures a radical improvement of quality } \\
\text { and competitiveness; } \\
\quad-\text { a lack of computer aided quality management systems (QMS) at } \\
\text { factories and plants of MME exporters; computer aided QMS are systems that are } \\
\text { decisive in carrying out a look back/routine/predictive analysis of causes for and } \\
\text { repair costs of defects/failures of elements, components, parts and units of each } \\
\text { item individually and all the products collectively throughout their lifecycle } \\
\text { stages (a mandatory requirement of the new Russian GOST Standards R ISO } \\
\text { 9000, version as of 2000); } \\
\quad-\text { a lack, at factories and plants of MME exporters, of state-of-the-art } \\
\text { systems of metrological assurance of the quality of MME products and efficient } \\
\text { quality management systems (QMS) ensuring production loss minimization at all } \\
\text { stages of product lifecycle; }\end{array}$ \\
\hline Legal reasons & $\begin{array}{l}\text { - the framework of standards en force in the area of development, } \\
\text { manufacture and operation of weapons and military equipment (WME) was } \\
\text { adopted and introduced } 25 \text { - } 30 \text { years ago and do not conform to the current } \\
\text { economic conditions and technical production specifications any longer; } \\
\text { - existing standardisation and compliance assessment systems do not } \\
\text { comply with the requirements of Federal Law of the Russian Federation "On } \\
\text { technical regulations" and international standards; } \\
\text { - absence of a mandatory condition to have an effective QMS in place at } \\
\text { factories (in developed economies) for procuring government defence contracts; } \\
\text { - use of CALS-technologies in the process of their development, } \\
\text { manufacture, operation and disposal }\end{array}$ \\
\hline $\begin{array}{l}\text { Organisational } \\
\text { reasons }\end{array}$ & $\begin{array}{l}\text { - incompliance by contractors with the procedure and methods of WMEs } \\
\text { testing for their acceptance for service in the Russian army and for exporting } \\
\text { them; } \\
\text { - absence of effective QMS at factories and, as a consequence, poorer }\end{array}$ \\
\hline
\end{tabular}


detection and shooting of troubles and defects in the design, production and operation of products;

- Violations of previously en-force procedures of control and maintenance of WME's quality in the chain of cooperation among developers, manufacturers and users of defence products; absence of an efficient system of personnel training in the area of quality management.

Basic principles of state policy on development of the defence industrial sector (DIS) require that defence contractors have in place efficient quality management systems (QMS). State defence standards provide for special requirements from state contracting authorities along with the forms and the order of assessment of QMS's compliance with applicable requirements.

For companies producing and supplying defence materials and equipment there is a special industrial standard GOST RV 0015-002-2012 "A system of developing defence equipment and launching it into manufacture. Quality management system. General requirements" (GOST RV 0015002-2012, 2012); the standard is obligatory. Compliance with its requirements guarantees the development, supply and servicing of products that can meet the standards applicable to military equipment supply, ensures its reliability and also implies measures of risk assessment and state secrets protection (GOST RV 0015-002-2012, 2012).

For the purposes of overcoming the existing problems in the defence industry sector and creating conditions for maintenance of the quality of defence products the following is to be implemented:

- Fundamental replacement of fixed production assets and experimenting/testing facilities at the industry's key companies and organisations;

- maintaining unique materials technologies used for modern weapons;

- protecting the defence potential of the weapons industry from unreasonable process reengineering and dissolution of the production facilities that have strategic significance for the manufacture of end products with desired properties;

- maintaining the talent pool at defence companies and organisations; attracting young specialists and workforce, their training and qualification testing;

- increasing the role of company leaders in ensuring systems management and quality management in particular;

- improving the methods of defence products quality control by the state client and of certifying by authorized certification systems;

- ensuring appropriate work load for defence companies and organisations above the limits that are necessary for maintaining steady and sustainable production processes;

- A systematic development and improvement of the legal framework in the area of defence industry operation and state order fulfilment.

As of today, in order to solve the issues of military equipment and materials quality, what we need is not simply certification and control by the state client: we also need a comprehensive system of ensuring and guaranteeing the quality of defence products that (system) could unite in itself both the military technical policy and state procurement requirements, control and supervision over compliance with technical specifications and defence standard requirements, appropriate metrology methods and testing procedures, along with independent compliance assessment procedures. A visualisation of such a system can be seen on Fig. 3 .

\section{Findings and inferences}

The present study of the three industry sectors (machine-tool engineering, radio electronics, defence materials and equipment) in Russia, in our view, is a proof of the existence of grave problems with maintenance of industrial products quality.

In addition to the identified specific problems and reasons of low level of quality manufactured products of analyzed branches of the national economy of Russia, it is worthwhile to 
pay attention to the insufficient level of professional skills of Russian industrialists due to modern requirements and functioning rules of the world economy and the active introduction of innovative industrial technologies.

A significant part of efforts of heads of national corporations and large enterprises should be focused on studying the best practical experience of quality assurance of worldwide leading manufacturers of industrial products and its active application. Great role also should be playing by system of Russian education, which is also interested in the preparation of qualified competitive personnel.

As a result improvement of activities aimed at ensuring higher products quality and bettering customer satisfaction will come from efficient practical management solutions, which, in its turn, will be conductive to an increase in positive outcomes of deployment and operation of quality management systems at Russian industrial enterprises.

\section{Conclusion}

Underestimation of the issue of industrial products quality and a need for systematic and focused efforts to improve it is what leads Russian industrial companies to a loss of ground in many a key sector. Only by facing up to the strategic importance of the problem of quality, by choosing and implementing appropriate systems of quality management at our plants and factories can we come closer to a perspective of ensuring a better competitive strength and sustainability to our business enterprises.

In conclusion, it would like to note that actions for solving problems identified in this article should have a systemic complex character. There is some degree of closeness and limited access to the analysis of the real situation at the enterprises industries in Russia. However, taking into account the importance of machine-tool construction, radio electronics and defense industries for the overall development of the economy, it is worthwhile to continue actively study and analyze the state of affairs in these industries, emphasizing quality assurance of products.

\section{Conflict of interests}

The authors of the paper confirm and guarantee that there are no conflicts of interests related hereto.

\section{Acknowledgments}

The study was carried out with the help, support and collaboration of the faculty of Industrial Economics Department at G. Plekhanov Russian University of Economics.

\section{References}

Afefy I.H., El-kamash A.M., El-Sayar N.M., 2015. Implementation of systems Engineering lifecycletools-model framework on large Industrial scale, Jordan Journal of Mechanical and Industrial Engineering 9 (4), 303-317

Baurina S.B., 2016. Modern machine-tool construction: questions and problems of quality assurance. Scientific researches and developments. The economy of the firm, 2, 26.

Bobalo Y., Nedostup L., Kiselychnyk M., Melen M., 2016. Problems of adequate modelling of the radio electronic device parameter distributions, Proceedings of 2016 17th International Conference Computational Problems of Electrical Engineering, CPEE 7738753

GOST RV 0015-002-2012, 2012. System for the development and production of military equipment. Quality management systems. General requirements [Electronic. resource]. - Access mode: http:/ / docs.cntd.ru/document/gost-rv-0015-002-2012. - Ver. From the screen.

Guerra L., Sousa S.D., Nunes E.P., 2016. Statistical process control in the final inspection process: An industrial case study, IEEE International Conference on Industrial Engineering and Engineering Management.

Kubela T., Pochyly A., Singule, V., 2016. Evaluation of industrial robots for accuracy in relation to accuracy in machining processes. Proceedings 2016 IEEE International Power Electronics and Motion Control Conference, PEMC 7752083, pp. 720-725 
Ministry of Industry and Trade of Russia, 2016. Report on the goals and objectives of the Ministry of Industry and Trade of Russia for 2016 and the main results of activities for 2015 [Electron. resource]. - Access mode:

http:/ / minpromtorg.gov.ru/common/upload/files/docs/Doklad_MPT_072016.pdf .

Nazarova E.V. Sycheva EI, Egorova NE, et al., 2016. Theoretical and methodological aspects of the organization's innovation activity: monography, O.E. Ryazan ed. - Moscow: IIU MGOU.

State program, 2012. Development of the electronic and radio electronic industry for 2013-2025, [Electron. resource]. Access mode: http://government.ru/programs/249/events/

State program, 2014. Development of industry and increase of its competitiveness for the period up to 2020, [Electron. resource]. - Access mode:

http:/ / innovation.gov.ru/sites/default/files/documents/2014/11065/2561.pdf

Vershinina A. A., Liudmila V. Goryainova, Zhdanova O. A., Maksimova T. P., 2016. State of the Investment Fund Market of as an Indicator of the Country's Socio-Economic Development. Journal of Internet Banking and Commerce. Special Issue: Finance, Services Sector and Commerce: Innovations and Investments, 21(3).

Vershinina A. A., Zhdanova O. A., Maksimova T. P., Perepelitsa D. G., 2015. The formation of the indicator framework for effective assessment of investment attractiveness of the region. International Journal of Economics and Financial Issues, 5(3), 136-141.

Wan S., Li D., Gao J., Roy R., Tong Y., 2016. Computers and Industry 84, 14-24 